\title{
Impact of Admission, Fasting Glucose and HbA1c Levels on in-stent Restenosis in The Patients Treated with Primary Percutaneous Coronary Intervention in 5-Year Follow-up
}

\author{
Beş Yıllık Izlemde HbA1c, Başvuru ve Açlık Kan Şekeri Düzeylerinin Primer \\ Perkütan Koroner Girişim Yapılan Hastalarda in-Stent Restenozuna Etkisi
}

\author{
๑ Fatma Özpamuk Karadeniz, • Yusuf Karadeniz*, • Barış Güngör ${ }^{\star *}$, ๑ Mehmet Eren ** \\ Private Büyükşehir Hospital, Clinic of Cardiology, Konya, Turkey \\ ${ }^{*}$ Necmettin Erbakan University Faculty of Medicine, Department of Internal Medicine, Division of Endocrinology and Metabolism, \\ Konya, Turkey \\ ** University of Health Science Turkey, Dr. Siyami Ersek Thoracic and Cardivascular Surgey Troining and Research Hospital, Clinic of \\ Cardiology, Istanbul, Turkey
}

Abstract

Aim: Despite advances in-stent technology, in-stent restenosis (ISR) is still a major problem following percutaneous coronary intervention $(\mathrm{PCI})$ and its reasons have not been fully revealed. In the presented study, we investigated the effect of admission blood glucose (ABG), fasting blood glucose (FBG) and glycated hemoglobin A1c (HbA1c) levels on coronary ISR patients with ST-elevation myocardial infarction (STEMI) who underwent primary PCl in five-year follow-up.

Methods: From 2.900 patients who underwent coronary stent implantation for STEMI from January 2008 through December 2012 were retrospectively analyzed through the hospital digital recording system. Of these, 264 patients who underwent control coronary angiography during the five-year follow-up were included in the study. Patients were divided into two main group ISR and non-ISR; were divided into two subgroups diabetic and non-diabetic groups were compared with $\mathrm{HbA1c}, \mathrm{ABG}, \mathrm{FBG}$ and angiographic parameters.

Results: There were 127 patients in the ISR group (diabetic: 36 nondiabetic: 91) and 137 patients in the non-ISR group (diabetic: 43 nondiabetic: 94). Regardless of the patients diabetes status, no significant difference was found between the groups with and without ISR in terms of $\mathrm{HbA} 1 \mathrm{C}, \mathrm{FBG}$ and $\mathrm{ABG}$. A significant relationship was found between the baseline $\mathrm{HbA} 1 \mathrm{c}$ value and having ISR only in the diabetic subgroup $(p=0.01)$.

Conclusion: This study results showed that in diabetic STEMI patients who underwent primary $\mathrm{PCl}$, higher $\mathrm{HbA} 1 \mathrm{c}$ levels were associated with higher ISR rates, but not with FBG and ABG levels.

Keywords: ST elevation myocardial infarction, blood glucose, glycated hemoglobin A1c, percutaneous coronary intervention, coronary angiography, coronary restenosis, diabetes mellitus
Öz

\begin{abstract}
Amaç: Stent teknolojisindeki ilerlemelere rağmen perkütan koroner girişimi (PKG) takiben gelişen in-stent restenozu (ISR) halen önemli bir sorundur ve nedenleri tam olarak ortaya konulamamıştır. Sunulan çalışmada primer PKG uygulanmış ST-segment yükselmeli akut miyokard enfarktüsü (STEMI) hastalarında başvuru kan şekeri (BKŞ), açlık kan şekeri (AKŞ) ve HbA1c düzeylerinin 5 yıllık izlemde koroner ISR üzerine etkisi analiz edildi.
\end{abstract}

Yöntemler: Ocak 2008-Aralık 2012 tarihleri arasında STEMI nedeniyle koroner stent implantasyonu uygulanan 2.900 hasta, hastane dijital kayıt sisteminden geriye dönük olarak incelendi. Bunlardan beş yıllık takipte kontrol koroner anjiyografisi yapılan 264 hasta çalışmamıza dahil edildi. Hastalar ana grup olarak ISR ve non-ISR; alt grup olarak ise diyabetik ve diyabetik olmayanlar olarak ayrıldı ve gruplar $\mathrm{HbA} 1 \mathrm{c}$, BKŞ, AKŞ ile birlikte anjiyografik parametreler açılarından karşılaştırıldı.

Bulgular: ISR grubunda toplam 127 hasta (diyabetik: 36 non-diyabetik 91) ve non-ISR grubunda toplam 137 hasta (diyabetik: 43 non-diyabetik: 94) mevcuttu. Hastaların diyabetik olup olmamasına bakılmaksızın, ISR olan ve olmayan gruplar arasında AKŞ, BKŞ ve HbA1c değerleri açısından anlamlı fark saptanmadı. Sadece diyabetik alt grupta HbA1c değeri ile ISR arasında anlamlı ilişki saptandı $(p=0,01)$.

Sonuç: Çalışma sonuçlarımız, primer PKG uygulanan diyabetik STEMI hastalarında yüksek HbA1c düzeylerinin daha yüksek ISR oranlarıly ilişkili olduğunu, fakat BKŞ ve AKŞ düzeyleri ile ilişkili olmadığını gösterdi.

Anahtar Sözcükler: ST yükselmeli miyokard enfarktüsü, kan glukozu, glikozile hemoglobin A1c, perkütan koroner girişim, koroner anjiyografi, koroner restenoz, diabetes mellitus
Address for Correspondence/Yazışma Adresi: Fatma Özpamuk Karadeniz, Private Büyükşehir Hospital, Clinic of Cardiology, Konya, Turkey

Phone: +90 5072334020 E-mail: kdrfatmakaradeniz@gmail.com ORCID: orcid.org/0000-0001-5839-9104 Received/Geliş Tarihi: 02.01.2021 Accepted/Kabul Tarihi: 27.01.2021
${ }^{0}$ Copyright 2021 by The Medical Bulletin of istanbul Haseki Training and Research Hospital The Medical Bulletin of Haseki published by Galenos Yayınevi. ${ }^{\circledR}$ Telif Hakkı 2021 istanbul Haseki Eğitim ve Araștırma Hastanesi Haseki Tıp Bülteni, Galenos Yayınevi tarafından yayınlanmıştır. 


\section{Introduction}

Restenosis is defined as a decrease in the luminal diameter after the percutaneous coronary intervention $(\mathrm{PCl})$, regarding if the stent is implanted or not. In-stent restenosis (ISR) is often defined as the restenosis anywhere between $5 \mathrm{~mm}$ from the proximal or distal edges of the stent associated with the loss of more than $50 \%$ of the diameter of the vessel which had been successfully treated (1-2). The most important limitations of the successful treatment of stenotic coronary artery through $\mathrm{PCl}$ are acute or late stent thrombosis and ISR.

Despite significant advances in interventional techniques such as new-generation bare-metal stents (BMS), drug-eluting stents (DES), drug-coated balloons, and drug therapies, ISR remains a significant problem in interventional cardiology, especially in diabetic patients (36). Diabetes mellitus (DM) is a critical patient-related cause in the pathogenesis of ISR (7). Glycosylated hemoglobin is a biomarker for the time-integrated average blood glucose and is assessed clinically with glycated hemoglobin A1c $(\mathrm{HbA} 1 \mathrm{c}) . \mathrm{HbA} 1 \mathrm{c}$ is used increasingly and more commonly for screening during the management of diabetes. $\mathrm{HbA} 1 \mathrm{c}$ is more closely related to the total risk of complications in DM than other (single or intermittent) measurements of blood glucose level (8). HbA1c provides a simple method to assess a patient's DM status and prognosis of coronary stent implantation in terms of ISR and other cardiovascular outcomes $(9,10)$.

In the last century, although many studies have been conducted on ISR, but it has not been clearly revealed which patients are susceptible to ISR both in diabetic and non-diabetic patients. This study aimed to evaluate the relationship between ISR and $\mathrm{HbA} 1 \mathrm{c}$, admission blood glucose (ABG), and fasting blood glucose (FBG) in diabetic and non-diabetic patients.

\section{Methods}

\section{Patient Population}

The study protocol was in accordance with the Declaration of Helsinki and approved by the local Dr. Siyami Ersek Hospital) Ethics Committee (13.08.2013 date and 2. number decision). We accessed hospital digital records retrospectively for the patients who underwent coronary stent implantation for ST-segment elevation myocardial infarction (STEMI) from January 2008 through December 2012 from a total of 2.900 patients. Among these patients, 2.636 patients who did not have control coronary angiography during the five-year follow-up were excluded. In those patients, we included 264 patients whose control coronary angiography was performed because of a stable angina pectoris, unstable angina pectoris, non-STEMI, and
STEMI during the five-year follow-up. ISR was detected in 127 patients, and no-ISR was detected in 137 patients.

Those who had a history of diabetes and used a restrictive diet, oral hypoglycemic medication, or insulin or those with an FBG level of $\geq 126 \mathrm{mg} / \mathrm{dL}$ on two occasions during hospitalization or an $\mathrm{HbA} 1 \mathrm{c}$ level $\geq 6.5 \%$ were evaluated as diabetic. DM was detected in 79 patients $(\mathrm{HbA} 1 \mathrm{c} \geq 6.5 \%) ; 185$ patients were non-diabetic (HbA1c $<6.5 \%)$.

The patients' clinical and demographic characteristics were noted, including age, gender, and histories of DM, arterial hypertension, hyperlipidemia, coronary artery disease (CAD), tobacco use, and medications.

\section{Laboratory Tests}

For each patient, FBG, ABG, HbA1c, low-density lipoprotein (LDL) cholesterol, high-density lipoprotein (HDL) cholesterol, triglycerides, total cholesterol, white blood cell count (WBC), hemoglobin, platelet count, and peak creatine kinase $M B$ isoenzyme $(C K M B)$ were measured in the first 24 hours of hospital admission. HbA1c was examined by immuno-turbidimetric method (Modular P800i, Roche, Germany) with the Tina-quant HgA1c II kit.

\section{Angiographic Parameters}

Current practice guidelines were followed for coronary interventions, and the data were recorded in digital storage for quantitative analysis. Access site for $\mathrm{PCl}$ was femoral with the Judkins technique. Two experienced interventional cardiologists estimated the degree of coronary stenosis visually. Significant stenosis was defined as a luminal narrowing of $>50 \%$ in a major subepicardial vessel (left anterior descending, left circumflex, or right coronary artery). After stent placement, clopidogrel was used for at least one year, and aspirin was used indefinitely. All treatments were given following the European Society of Cardiology guidelines. The patient adherence to medical therapy was standardized. Coronary angiography was performed secondarily during routine clinical follow-up in the patients with stable angina pectoris, unstable angina pectoris, non-STEMI, and STEMI. The Judkins technique was used to record control coronary angiograms. Two independent cardiologists who were blinded to the patients' data interpreted the angiograms. In coronary angiography, a narrowing of $>50 \%$ in $5-\mathrm{mm}$ proximal and the distal of the stent edge in an otherwise normal diameter was accepted as stent restenosis.

\section{Statistical Analysis}

Statistical Package for the Social Sciences (SPSS Windows version 20.0, IBM Corp, USA) was used in all analyses. Quantitative variables with a normal distribution were given as the mean \pm standard deviation, and those 
with non-normal distribution were given as the median (minimum and maximum). Chi-square test and Fisher exact test were used for categorical variables to compare the groups. Mann-Whitney $U$ test was used to compare the instruments of the two groups that were not normally distributed and the normal distributions were compared using the student's t-test. A p-value of $<0.05$ was considered statistically significant.

\section{Results}

Of the 264 patients in this study, 127 patients were diagnosed with ISR over $50 \%$ stenosis. There were 79 diabetic patients: 36 in the ISR group and 43 non-ISR group. The demographic characteristics of the patients and the risk factors were given in Table 1. Their baseline clinical

\begin{tabular}{|c|c|c|c|}
\hline & $\begin{array}{l}\text { ISR } \\
(n=127)\end{array}$ & $\begin{array}{l}\text { Non-ISR } \\
(n=137)\end{array}$ & $p$ \\
\hline Age (years), mean $\pm S D$ & $56.1 \pm 10.2$ & $56.8 \pm 10.8$ & 0.54 \\
\hline Gender male, n (\%) & $113(89 \%)$ & $69(50.4 \%)$ & 0.01 \\
\hline Female, n (\%) & $14(11 \%)$ & $68(49.6 \%)$ & 0.01 \\
\hline Hypertension, n (\%) & $64(50.4 \%)$ & $57(41.6 \%)$ & 0.37 \\
\hline Diabetes mellitus, $\mathrm{n}(\%)$ & $36(28.3 \%)$ & $43(31.4 \%)$ & 0.59 \\
\hline Insulin user, n (\%) & $2(5.5 \%)$ & $17(39.5 \%)$ & 0.01 \\
\hline Oral anti-diabetic user, n (\%) & $34(94.4 \%)$ & $26(60.4 \%)$ & 0.13 \\
\hline Hyperlipidemia, n (\%) & $54(42.5 \%)$ & $39(28.5 \%)$ & 0.18 \\
\hline Smoker, n (\%) & $71(55.9 \%)$ & $63(46 \%)$ & 0.31 \\
\hline $\begin{array}{l}\text { History of coronary artery } \\
\text { disease, } \mathrm{n}(\%)\end{array}$ & $19(15 \%)$ & $79(57.7 \%)$ & 0.01 \\
\hline
\end{tabular}

Table 2. Baseline angiographic parameters of the study population and treatment modality of ISR group

\begin{tabular}{|c|c|c|c|}
\hline & $\begin{array}{l}\text { ISR } \\
(n=127)\end{array}$ & $\begin{array}{l}\text { Non-ISR } \\
(n=137)\end{array}$ & p \\
\hline \multicolumn{4}{|l|}{ Culprit artery } \\
\hline LAD, n (\%) & $66(51.9 \%)$ & 73 (53.2\%) & \\
\hline$C X, n(\%)$ & $18(14.1 \%)$ & $29(21.1 \%)$ & 0.18 \\
\hline RCA, n (\%) & $43(33.8 \%)$ & $35(25.5 \%)$ & \\
\hline $\begin{array}{l}\text { Number of diseased vessels, } \\
\text { mean } \pm S D\end{array}$ & $1.80 \pm 0.79$ & $1.68 \pm 0.80$ & 0.23 \\
\hline $\begin{array}{l}\text { Stent diameter }(\mathrm{mm}) \text {, } \\
\text { mean } \pm S D\end{array}$ & $3.0 \pm 0.42$ & $2.98 \pm 0.75$ & 0.72 \\
\hline Stent length $(\mathrm{mm})$, mean $\pm \mathrm{SD}$ & $20.0 \pm 6.1$ & $17.7 \pm 6.0$ & 0.01 \\
\hline \multicolumn{4}{|l|}{ Treatment of stent restenosis } \\
\hline Medical, n (\%) & $18(14.1 \%)$ & - & - \\
\hline $\mathrm{PCl}, \mathrm{n}(\%)$ & $63(49.6 \%)$ & - & - \\
\hline CABG, n (\%) & $46(36.2 \%)$ & - & - \\
\hline \multicolumn{4}{|c|}{$\begin{array}{l}\text { LAD: Left anterior descending artery, CX: Circumflex artery, RCA: Right coronary } \\
\text { artery, CABG: Coronary artery by-pass grafting, SD: Standard deviation, ISR: In- } \\
\text { stent restenosis }\end{array}$} \\
\hline
\end{tabular}

characteristics were similar except they are more likely to be male in in ISR group and history of coronary artery disease is more common in non-ISR group. The vessels implanted with a stent in the primary $\mathrm{PCl}$, the number of vessels involved, and the restenosis treatment were shown in Table 2. The average stent diameter and length were $3.0 \pm 0.42$ and $20.0 \pm 6.1$ in the ISR group and $2.98 \pm 0.75$ and $17.7 \pm 6.0$ in the non-ISR group, respectively. The two groups did not differ significantly in terms of target vessel, lesion type classified according to American College of Cardiology/American Heart Association, and implanted stent type, size except length. Of the patients who developed ISR, 63 underwent repeat $\mathrm{PCl}, 46$ underwent coronary bypass operation, and 18 were followed up with drug treatment.

The laboratory parameters of the patients were detailed in Table 3. For the whole patient group, the mean $\mathrm{FBG}, \mathrm{ABG}$, and $\mathrm{HbA} 1 \mathrm{c}$ values were $121 \pm 5,171 \pm 85$, and $6.65 \pm 1.69$ in the ISR group and $118 \pm 41,169 \pm 83$, and $6.39 \pm 1.29$ in the non-ISR groups, respectively. The difference between the ISR and non-ISR groups was not statistically significant $(p>0.05)$. When these parameters were examined in the diabetic subgroup, there was no significant difference between the ISR and non-ISR groups regarding the $F B G(164 \pm 82$ vs. $152 \pm 53, p=0.44)$ and $A B G$ $(245 \pm 100$ vs. $229 \pm 105, p=0.53)$. However, a significant difference was found between the ISR and non-ISR groups regarding the $\mathrm{HbA} 1 \mathrm{c}$ values $(7.47 \pm 1.57$ vs. $8.60 \pm 1.82$, $p=0.01$ ) (Figure 1). The differences between the ISR and non-ISR groups in the diabetic patients regarding the demographic, angiographic, and laboratory parameters were given in Table 4.

\begin{tabular}{|c|c|c|c|}
\hline & $\begin{array}{l}\text { ISR } \\
(n=127) \\
\text { Mean } \pm \text { SD }\end{array}$ & $\begin{array}{l}\text { Non-ISR } \\
(n=137) \\
\text { Mean } \pm \text { SD }\end{array}$ & p \\
\hline Hemoglobin (mg/dL) & $14.1 \pm 1.4$ & $14.0 \pm 1.6$ & 0.21 \\
\hline Platelet $(103 / \mu \mathrm{L})$ & $295 \pm 80$ & $235 \pm 75$ & 0.25 \\
\hline 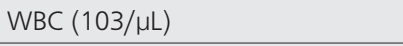 & $12.1 \pm 3.9$ & $11.9 \pm 4.6$ & 0.79 \\
\hline Creatinine (mg/dL) & $0.89 \pm 0.31$ & $0.88 \pm 0.22$ & 0.65 \\
\hline Peak-CKMB (IU/L) & $160 \pm 120$ & $195 \pm 140$ & 0.05 \\
\hline Total cholesterol (mg/dL) & $189 \pm 53$ & $184 \pm 43$ & 0.40 \\
\hline LDL cholesterol (mg/dL) & $116 \pm 41$ & $110 \pm 36$ & 0.20 \\
\hline HDL cholesterol (mg/dL) & $37 \pm 9$ & $39 \pm 10$ & 0.09 \\
\hline Triglyceride (mg/dL) & $130 \pm 108$ & $141 \pm 100$ & 0.77 \\
\hline Fasting blood glucose (mg/dL) & $121 \pm 5$ & $118 \pm 41$ & 0.61 \\
\hline Admission blood glucose (mg/dL) & $171 \pm 85$ & $169 \pm 83$ & 0,82 \\
\hline $\mathrm{HbA1c}(\%)$ & $6.65 \pm 1.69$ & $6.39 \pm 1.29$ & 0.17 \\
\hline \multicolumn{4}{|c|}{$\begin{array}{l}\text { SD: Standard deviation, WBC: White blood cell, CKMB: peak Creatine kinase MB } \\
\text { isoenzyme, LDL: Low-density lipoprotein, HDL: High-density lipoprotein, HbA1C: } \\
\text { Glycated hemoglobin A1c, ISR: In-stent restenosis }\end{array}$} \\
\hline
\end{tabular}




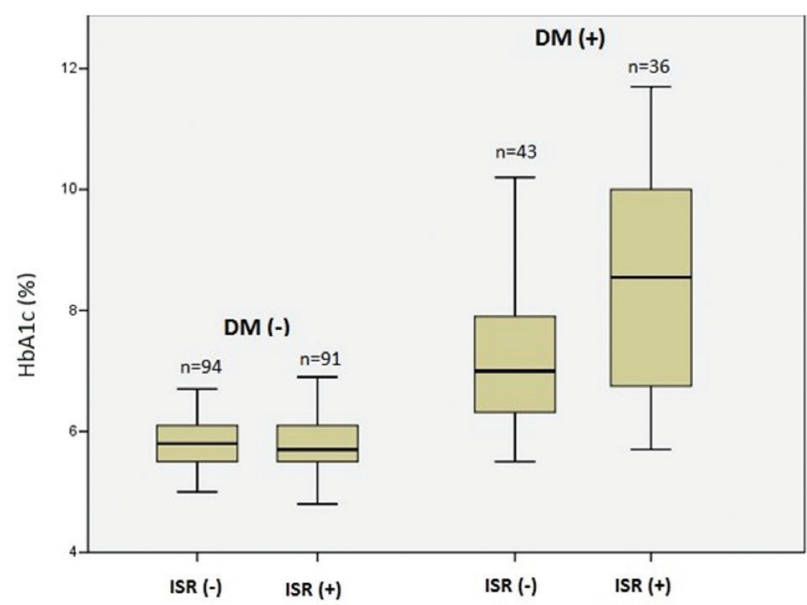

Figure 1. Comparison of in-stent restenosis with $\mathrm{HbA} 1 \mathrm{c}$ level in diabetic patients and non-diabetic group

ISR: In-stent restenosis, DM: Diabetes mellitus, HbA1c: Glycated hemoglobin A1C

\begin{tabular}{|c|c|c|c|}
\hline & $\begin{array}{l}\text { ISR } \\
(n=36)\end{array}$ & $\begin{array}{l}\text { Non-ISR } \\
(\mathrm{n}=43)\end{array}$ & $\mathbf{p}$ \\
\hline Age (years) mean \pm SD & $55.8 \pm 11.3$ & $58.1 \pm 8.8$ & 0.33 \\
\hline Gender male (n) (\%) & $32(88.8 \%)$ & $18(41.8 \%)$ & 0.01 \\
\hline Female $(n)(\%)$ & $4(11.1 \%)$ & $25(58.1 \%)$ & 0.01 \\
\hline Hypertension (n) (\%) & $25(69.4 \%)$ & $22(51.1 \%)$ & 0.20 \\
\hline Hyperlipidemia (n) (\%) & $20(55.5 \%)$ & $15(34.8 \%)$ & 0.06 \\
\hline $\begin{array}{l}\text { History of coronary artery } \\
\text { disease }(n)(\%)\end{array}$ & $6(16.6 \%)$ & $30(69.7 \%)$ & 0.01 \\
\hline Hemoglobin $(\mathrm{mg} / \mathrm{dL})$ mean $\pm \mathrm{SD}$ & $13.9 \pm 1.4$ & $13.7 \pm 1.9$ & 0.61 \\
\hline WBC $(103 / \mu \mathrm{L})$ mean \pm SD & $12.1 \pm 3.9$ & $11.9 \pm 4.6$ & 0.79 \\
\hline Creatinine $(\mathrm{mg} / \mathrm{dL})$ mean $\pm \mathrm{SD}$ & $0.89 \pm 0.31$ & $0.88 \pm 0.22$ & 0.46 \\
\hline Peak CKMB (IU/L) mean \pm SD & $115 \pm 84$ & $205 \pm 150$ & 0.02 \\
\hline $\begin{array}{l}\text { Total cholesterol }(\mathrm{mg} / \mathrm{dL}) \\
\text { mean } \pm \text { SD }\end{array}$ & $192 \pm 48$ & $189 \pm 49$ & 0.79 \\
\hline $\begin{array}{l}\mathrm{LDL} \text { cholesterol }(\mathrm{mg} / \mathrm{dL}) \\
\text { mean } \pm \mathrm{SD}\end{array}$ & $112 \pm 44$ & $115 \pm 39$ & 0.71 \\
\hline $\begin{array}{l}\mathrm{HDL} \text { cholesterol }(\mathrm{mg} / \mathrm{dL}) \\
\text { mean } \pm \mathrm{SD}\end{array}$ & $36 \pm 10$ & $38 \pm 9$ & 0.31 \\
\hline Triglyceride $(\mathrm{mg} / \mathrm{dL})$ mean $\pm \mathrm{SD}$ & $151 \pm 109$ & $159 \pm 121$ & 0.48 \\
\hline $\begin{array}{l}\text { Fasting blood glucose }(\mathrm{mg} / \mathrm{dL}) \\
\text { mean } \pm \text { SD }\end{array}$ & $164 \pm 82$ & $152 \pm 53$ & 0.44 \\
\hline $\begin{array}{l}\text { Admission blood glucose (mg/ } \\
\mathrm{dL} \text { ) mean } \pm \text { SD }\end{array}$ & $245 \pm 100$ & $229 \pm 105$ & 0,53 \\
\hline $\mathrm{HbA} 1 \mathrm{c}(\%)$ mean $\pm \mathrm{SD}$ & $8.60 \pm 1.82$ & $7.47 \pm 1.57$ & 0.01 \\
\hline Stent diameter $(\mathrm{mm})$ mean \pm SD & $3.02 \pm 0.32$ & $2.96 \pm 0.78$ & 0.69 \\
\hline Stent length $(\mathrm{mm})$ mean $\pm \mathrm{SD}$ & $20.41 \pm 5.48$ & $18.53 \pm 5.69$ & 0.15 \\
\hline \multicolumn{4}{|c|}{$\begin{array}{l}\text { SD: Standard deviation, WBC: White blood cell count, CKMB: peak creatine } \\
\text { kinase MB isoenzyme, LDL: Low-density lipoprotein, HDL: High-density } \\
\text { lipoprotein, HbA1c: Glycated hemoglobin A1c, ISR: In-stent restenosis }\end{array}$} \\
\hline
\end{tabular}

\section{Discussion}

It is well known that DM is associated with an increased of cardiovascular mortality and plays a main role in ISR development (11). Additionaly, it is shown that ISR was an independent risk factor for mortality (12). The results of this study evaluated the effects of $F B G, A B G$, and $\mathrm{HbA} 1 \mathrm{c}$ on the long-term ISR rate in both diabetic and nondiabetic patients who underwent primary $\mathrm{PCl}$. Our study shows that admission HbA1c levels are associated with higher ISR rates in a diabetic STEMI population treated with primary $\mathrm{PCl}$. Our findings are supported with several previous studies reporting increased rates of ISR following $\mathrm{PCl}$ in uncontrolled diabetic patients (13-15).

Measurement of $\mathrm{HbA} 1 \mathrm{c}$ levels with $\mathrm{ABG}$ and FBG levels in non-diabetic patients may improve risk assessment in patients presenting with acute STEMI. Our study showed no association between these parameters and ISR rates in non-diabetic patients. Naito et al. (13) investigated the effects of $\mathrm{ABG}$ and $\mathrm{HbA} 1 \mathrm{c}$ on the long-term PCl outcomes in 452 non-diabetic patients presenting with acute coronary syndrome (ACS). They showed that the ABG and $\mathrm{HbA} 1 \mathrm{c}$ values were independently correlated with the clinical outcomes in non-diabetic ACS patients treated with $\mathrm{PCl}(13)$. This association is supported by some other works $(16,17)$. Our investigation could not demonstrate this association. The reason of this can be low number of study patients in this study and glucose variability.

In an other study high HbA1c levels were suggested to predict cardiovascular disease frequency and mortality in non-diabetic patients, independent of FBG (18). Pai et al. (19) showed in their study that increasing HbA1c levels increases the risk of coronary artery disease in patients with diabetes and non-diabetic patients. In a meta-analysis by Cavero-Redondo et al. (10), a relationship was found between $\mathrm{HbA} 1 \mathrm{c}$ levels and mortality and cardiovascular outcomes in both diabetic and non-diabetic patients. In their analysis, all-cause mortality was higher when $\mathrm{HbA} 1 \mathrm{c}$ levels were over $6 \%$ and $8 \%$ in non-diabetic and diabetic patients, respectively (10).

The development of ISR is a complex and multifactorial process; there are patient-, vessel-, and procedure-related factors involved (20). Among the identified factors associated with the patient, DM was considered one of the high-risk clinical predictors for ISR, which was found to be 30-50\% following BMS implantations (21). Although the rate of ISR in DES was found to be lower than that in BMS, it was higher in diabetic patients compared to nondiabetic patients $(22,23)$. In a meta-analysis, an association was found between $\mathrm{HbA} 1 \mathrm{c}$ level and cardiovascular outcomes in diabetic patients after $\mathrm{PCl}$ (24). Anatomically, both lesion length and lesion diameter are predictors of ISR. Generally, the length of the lesion and the narrow 

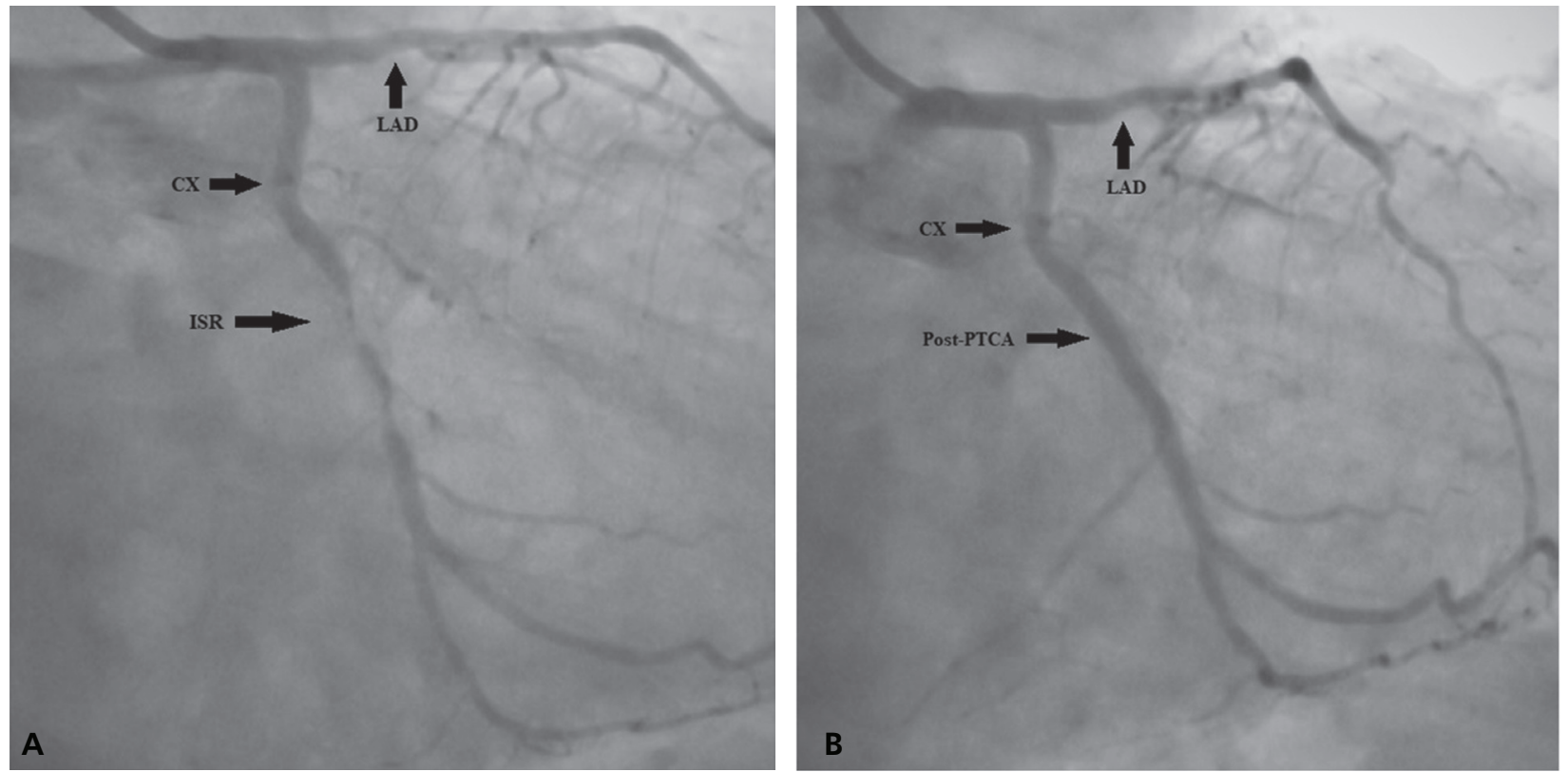

Figure 2. A) In-stent critical lesion in CX coronary artery, B) After treatment with PTCA in stenotic CX coronary artery

Example of ISR case report: 65 years old patient presented with chest pain. He had a history of hypertension, diabetes mellitus and primary $\mathrm{PCl}$ to $\mathrm{CX}$ coronary artery due to acute inferior $\mathrm{Ml}$ two years ago. His HbA1c, ABG and FBG levels were $10.1 \%, 187 \mathrm{mg} / \mathrm{dL}, 150$ $\mathrm{mg} / \mathrm{dL}$ respectively during admission. A control CAG was performed with the diagnosis of non-STEMI. The control CAG revealed $95 \%$ ISR in CX coronary artery. Percutan transluminal coronary angioplasty is performed into restenotic segment and full openness was achieved. LAD: Left anterior descending artery, CX: Circumflex artery, PTCA: Percutaneous trans/uminal coronary angioplasty

diameters have been shown to increase the incidence of ISR (22). In the diabetic subgroup in our study, no significant difference was found between the ISR and nonISR groups in terms of stent length and diameter. Since our hospital is a tertiary center for cardiovascular diseases and all angiographies are performed by two experienced cardiologists, the factors related to ISR procedures were standardized.

$\mathrm{HbA1c}$ is an important marker revealing the long-term glycemic follow-up of diabetic patients. Increased HbA1c levels are associated with microvascular and macrovascular complications. In our study, the reasons for not finding a significant relationship between the ISR and ABG or FBG, as opposed to $\mathrm{HbA} 1 \mathrm{c}$, could be that $\mathrm{HbA} 1 \mathrm{c}$ does not require fasting, its biological variability and irregularity before analysis is less, and it is not affected by acute changes in blood glucose levels. In previous studies, microvascular and macrovascular symptoms of diabetes were observed above the limit value of $6.5 \%$; an $\mathrm{HbA} 1 \mathrm{c}$ cut-off value of $\geq 6.5 \%$ was established for the diagnosis of DM in the last report of the American Diabetes Association (9). For this reason, we took the $\mathrm{HbA} 1 \mathrm{c}$ cut-off as $6.5 \%$ in this study.

The clinical manifestation of ISR commonly includes recurring angina symptoms or ACS, and it may lead to a re-intervention either with coronary artery bypass or repeat PCI (25). We presented an example case about ISR (Figure 2A-B)

\section{Study Limitations}

This study analyzed the data derived from a single center. An important limitation of our study is the low number of study patients. In addition, since our study was retrospective, the patients' glycemic control during their long follow-up period could not be corroborated. Although the restenosis rates of DESs were found to be lower in diabetic patients in recent studies, a BMS was applied in our study. Although the HbA1c level was affected in the patients with low hemoglobin levels and hemoglobinopathy, the patients with anemia were excluded from our study, and the measuring device we used did not interact with abnormal hemoglobin.

\section{Conclusion}

$\mathrm{HbA1C}$ is strong independent predictor of ISR in patients with DM after coronary stent implantation. Our findings supported that strict diabetes control such as prescribing aggresive glucose lowering medication will reduce ISR rates in the subpopulation of DM patients. This relationship was not observed in non-diabetic patients. Extensive, randomized studies are needed to further demonstrate this relationship both in non-diabetic patients.

\section{Authorship Contributions}

Concept: F.Ö.K., Design: F.Ö.K., M.E., Data Collection or Processing: F.Ö.K., Y.K., Analysis or Interpretation: B.G., Literature Search: F.Ö.K., Writing: F.Ö.K., Y.K. 
Conflict of Interest: No conflict of interest was declared by the authors.

Financial Disclosure: The authors declared that this study received no financial support.

\section{References}

1. Pompa JJ, Bhat DL. Percutaneous Coronary Intervention. In:Bonow RO, Mann DL, Zipes DP, Libby P eds. Braunwald's Heart Disease, Ninth Edition, Philidelphia, USA: Elsevier Saunders; 2012. pp. 1452-3

2. Pleva L, Kukla $P$, Hlinomaz $O$. Treatment of coronary in-stent restenosis: a systematic review. J Geriatr Cardiol 2018;15:17384.

3. Nicolais C, Lakhter V, Virk HUH, et al. Therapeutic options for in-stent restenosis. Curr Cardiol Rep 2018;20:7.

4. Stone GW, Ellis SG, Cannon L, et al. Comparison of a polymerbased paclitaxel-eluting stent with a bare metal stent in patients with complex coronary artery disease: a randomized controlled trial. JAMA 2005;294:1215-23.

5. McKavanagh P, Zawadowski G, Ahmed N, Kutryk M. The evolution of coronary stents. Expert Rev Cardiovasc Ther 2018;16:219-28.

6. Buccheri D, Lombardo RM, Cortese B. Drug-coated balloons for coronary artery disease: current concepts and controversies. Future Cardiol 2019;15:437-54.

7. Kassaian SE, Goodarzynejad H, Boroumand MA, et al Glycosylated hemoglobin (HbA1c) levels and clinical outcomes in diabetic patients following coronary artery stenting. Cardiovasc Diabetol 2012;11:82.

8. American Diabetes Association. 2. Classification and Diagnosis of Diabetes: Standards of Medical Care in Diabetes-2020. Diabetes Care 2020;43(Suppl 1):S14-S31.

9. Gustafsson I, Kistorp CN, James MK, Faber JO, Dickstein K, Hildebrandt PR; OPTIMAAL Study Group. Unrecognized glycometabolic disturbance as measured by hemoglobin A1C is associated with a poor outcome after acute myocardial infarction. Am Heart J 2007;154:470-6.

10. Cavero-Redondo I, Peleteiro B, Álvarez-Bueno C, RodriguezArtalejo F, Martínez-Vizcaíno V. Glycated haemoglobin A1c as a risk factor of cardiovascular outcomes and all-cause mortality in diabetic and non-diabetic populations: a systematic review and meta-analysis. BMJ Open 2017;7:e015949.

11. Zhao L, Zhu W, Zhang $X$, He D, Guo C. Effect of diabetes mellitus on long-term outcomes after repeat drug-eluting stent implantation for in-stent restenosis. BMC Cardiovasc Disord 2017;17:16.

12. Cassese S, Byrne RA, Schulz S, et al. Prognostic role of restenosis in 10004 patients undergoing routine control angiography after coronary stenting. Eur Heart J. 2015;36:94-9.

13. Naito $R$, Miyauchi K, Ogita M, et al. Impact of admission glycemia and glycosylated hemoglobin A1c on long-term clinical outcomes of non-diabetic patients with acute coronary syndrome. J Cardiol 2014;63:106-11.

14. Corpus RA, George PB, House JA, et al. Optimal glycemic control is associated with a lower rate of target vessel revascularization in treated type II diabetic patients undergoing elective percutaneous coronary intervention. J Am Coll Cardiol 2004;43:8-14.

15. Cicek $G$, Uyarel $H$, Ergelen $M$, et al. Hemoglobin $A 1 C$ as a prognostic marker in patients undergoing primary angioplasty for acute myocardial infarction. Coron Artery Dis. 2011;22:131-7.

16. Timmer JR, Hoekstra M, Nijsten MW, et al. Prognostic value of admission glycosylated hemoglobin and glucose in nondiabetic patients with ST-segment-elevation myocardial infarction treated with percutaneous coronary intervention. Circulation 2011;124:704-11.

17. Ertem AG, Bağbancı H, Kılıç H, Yeter E, Akdemir R. Relationship between $\mathrm{HbA} 1 \mathrm{c}$ levels and coronary artery severity in nondiabetic acute coronary syndrome patients. Turk Kardiyol Dern Ars 2013;41:389-95.

18. Khaw KT, Wareham N. Glycated hemoglobin as a marker of cardiovascular risk. Curr Opin Lipidol 2006;17:637-43.

19. Pai JK, Cahill LE, Hu FB, Rexrode KM, Manson JE, Rimm EB. Hemoglobin a1c is associated with increased risk of incident coronary heart disease among apparently healthy, nondiabetic men and women. J Am Heart Assoc 2013;2:e000077.

20. Kim MS, Dean LS. In-stent restenosis. Cardiovasc Ther 2011;29:190-8.

21. Mathew V, Gersh BJ, Williams BA, et al. Outcomes in patients with diabetes mellitus undergoing percutaneous coronary intervention in the current era: a report from the Prevention of REStenosis with Tranilast and its Outcomes (PRESTO) trial. Circulation 2004; 109:476-80.

22. Lemos PA, Hoye A, Goedhart D, et al. Clinical, angiographic, and procedural predictors of angiographic restenosis after sirolimus-eluting stent implantation incomplex patients: An evaluation from the Rapamycin-Eluting Stent Evaluated At Rotterdam Cardiology Hospital (RESEARCH) study. Circulation 2004;109:1366-70.

23. Kastrati A, Dibra A, Mehilli J, et al. Predictive factors of restenosis after coronary implantation of sirolimus- or paclitaxel-eluting stents. Circulation 2006;113:2293-300.

24. Zheng J, Cheng J, Zhang Q, Qi C, Wang T, Xiao X. Association between glycosylated hemoglobin level and cardiovascular outcomes in diabetic patients after percutaneous coronary intervention. Medicine (Baltimore) 2016;95:e3696.

25. Cassese S, Byrne RA, Schulz S, et al. Prognostic role of restenosis in 10004 patients undergoing routine control angiography after coronary stenting. Eur Heart J 2015;36:949. 